\title{
MAKNA KEBERAGAMAAN MAHASISWA PENERIMA BEASISWA STAIN KUDUS
}

\author{
MEANING OF RELIGIUSITY OF STUDENT BIDIKMISI STAIN KUDUS
}

Efa Ida Amaliyah

IAIN Kudus Jln. Conge Ngembalrejo Po.Box. 51 Kudus

email: efa@stainkudus.ac.id

Naskah Diterima: 25 Juli 2019; Direvisi: 02 Maret 2020; Disetujui: 16 Desember 2020

\begin{abstract}
This study reveals two things, firstly the significance of religiosity and the secondly, the form of religiosity according to Bidikmisi STAIN Kudus students. This research was conducted on STAIN Kudus students who received Bidikmisi scholarships, using a sociology approach. Bidikmisi students are students who have specialties in two fields, namely academic potential and Spiritual potential. In Academic potential, they have to compete with thousands of students, be preferred from the middle to lower classes. This is supported by good and satisfying academic abilities through tests conducted by the Ministry of Religion through STAIN Kudus. Spiritual potential, bidikmisi students get the opportunity to "appreciate" the STAIN Kudus mosque through religious activities. This activity affects their religiosity because it has a religious nuance. These activities include barzanji, ngaji kitab, maulid diba'an, yasinan and tahlil, qira'ah, and memorization of juz 'amma.
\end{abstract}

Keywords: Bidikmisi; Religiusity; Scholarship; Student

\begin{abstract}
Abstrak
Penelitian ini bertujuan untuk mengungkap dua hal yang berkenaan tentang makna keberagamaan mahasiswa bidikmisi STAIN Kudus Tahun Anggaran 2014 dan bentuk keberagamaan tersebut. Jenis penelitian ini adalah field research, yaitu penelitian yang dilakukan di lapangan atau medan terjadinya gejala-gejala dengan menggunakan dua pendekatan, yaitu pendekatan etik emik. Dalam pendekatan emik, mahasiswa memberikan makna sesuai apa yang dirasa, dilihat, dibayangkan dan difikirkan tentang keberagamaan. Hasil penelitian menunjukkan bahwa keberagamaan mahasiswa bidikmisi mempunyai makna yang berbeda sesuai dengan pengalaman dan lingkungan sosial budaya di lingkungan mereka. Mahasiswa bidikmisi merupakan mahasiswa yang mempunyai keistimewaan dalam dua bidang, yaitu bidang akademik dan bidang keagamaan. Potensi akademik bersaing dengan ribuan mahasiswa untuk mendapatkan predikat mahasiswa berprestasi. Mahasiswa tersebut merupakan mahasiswa yang secara ekonomi dari kalangan menengah ke bawah, sehingga mereka berjuang untuk mendapatkan predikat sebagai mahasiswa. Hal ini didukung oleh kemampuan akademik yang bagus dan memuaskan melalui tes yang diselenggarakan oleh Kemenag Pusat melalui STAIN Kudus. Potensi rohaniah, mahasiswa bidikmisi mendapatkan kesempatan untuk "memakmurkan" Masjid STAIN Kudus melalui kegiatan keagamaan. Memakmurkan masjid inilah yang mempengaruhi keberagamaan mahasiswa bidikmisi. Kegiatan ini yang mempengaruhi peningkatan keberagamaan mereka karena bernuansa agamis. Kegiatan tersebut antara lain barzanji, ngaji kitab, maulid diba'an, yasinan dan tahlil, qira'ah, dan hafalan juz 'amma.
\end{abstract}

Kata kunci: Beasiswa; Bidikmisi; Makna keberagamaan; mahasiswa 


\section{PENDAHULUAN}

Agama adalah keyakinan. Keyakinan merupakan satu bentuk hasil berfikir. Seseorang meyakini atau tidak meyakini sosok Tuhan; demikian pula memeluk atau tidak memeluk agama tertentu, merupakan hasil keputusan diri sebagai bentuk hasil berfikir. Keyakinan adalah sebuah kesadaran akal terhadap sebuah kebenaran tertentu, bahkan akal itu sendiri sering kesulitan untuk memahami keyakinan itu (Khadiq, 2009) .

Menurut (Hardjana, 2009) sebagaimana yang dikutip oleh Hamim Ilyas (Ilyas, 2014), Keimanan yang mendasari keberagamaan umat Islam dewasa ini pada umumnya merupakan keimanan dengan dimensi teologi yang kental, yakni keimanan yang menekankan pada apa yang harus diyakini sebagai doktrin yang benar dalam agama. Keimanan seperti ini hanya menghasilkan penghayatan agama, bukan penghayatan spiritualitas. Dalam penghayatan agama, doktrin menjadi satu-satunya pegangan pokok dalam menjalani agama. Sementara dalam penghayatan spiritualitas doktrin menjadi titik tolak untuk mengenal Tuhan lebih jauh dan semakin mendalam. Dengan keimanan yang menghasilkan penghayatan agama demikian maka keberagamaan umat Islam pun dominan formalistik. Maksudnya keberagamaan yang menekankan pada prosedur-prosedur dalam ritual dan kehidupan sosial. Keberagamaan ini sangat nyata dalam pelaksanaan ritual dan syiar agama yang semarak dengan siklus harian, mingguan dan tahunan; dan dalam pelaksanaan usaha penerapan simbol-simbol agama di ranah publik. Krisis multi-dimensi yang dialami umat Islam sekarang dapat dipastikan berhubungan dengan keberagamaan formalistik ini.

Agama bukan hanya menjadi bagian penting dari kecenderungan manusia dalam melakukan eksternalisasi dan membangun makna serta dunia social. Ia juga sebagai sarana untuk memperoleh legitimasi social atau pemeliharaan dunia (world maintenance). Agama juga bisa melegitimasi institusi dan keteraturan social dengan status ontologisnya, sehingga member legitimasi yang kuat dan objektif pada keteraturan social dan moral (Peter Carnolly, 1999).
Seseorang yang menganut agama, menjalankan ajaran agamanya sesuai dengan keyakinan. Karenanya, antara agama dan keberagamaan tidak dapat dipisahkan. Agama sebagai keyakinan, ajaran, dan pedoman hidup. Sedangkan, keagamaan adalah respon umat beragama dalam menjalankan ajaran agama tersebut. Karenanya, tiap orang berbeda dalam menjalankan keberagamaannya.

Dikaitkan dengan tinjauan menurut pandangan Islam, bahwa menurut Mahmud Syaltut (Hajar, 2005), ajaran Islam terdiri atas tiga bagian, yaitu akidah (kepercayaan atau keimanan), Syariah (hukum-hukum Agama, yang meliputi Ibadah dan muamalah), dan akhlak (budi pekerti). Atau dengan menggunakan istilah lain, Agama Islam itu terdiri atas tiga pilar, yaitu Iman, lslam, dan Ikhsan. Seseorang dikatakan mencapai derajat muslim yang kaffah jika dia telah melaksanakan tiga pilar ajaran itu dengan baik. Selengkapnya dalam kenyataannya di masyarakat, masih banyak yang perlu ditingkatkan kualitas keberagamaannya. Salah satu faktor penyebabnya adalah pengaruh perubahan zaman dengan ditandai kemajuan ilmu pengetahuan dan teknologi yang memunculkan pemikiran baru dan alat-alat teknologi canggih, yang dampaknya memiliki kecenderungan kearah positif dan negatif.

Masyarakat selama ini menganggap mahasiswa sebagai salah satu kelompok yang menjadi sub elemen penting masyarakat sebab memiliki potensi besar dalam menciptakan suatu bentuk tatanan tertentu. Mahasiswa adalah manusia yang dipenuhi idealisme. Mahasiswa dianggap tunas-tunas baru yang akan menggantikan peran para pemimpin di masa yang akan datang. Di tangan para mahasiswa masa depan bangsa ini akan bergantung. Tongkat estafet kepemimpinan ini akan diteruskan oleh mahasiswa (Bahari, 2010) (Subakri, 2004).

Banawiratma mengemukakan sudah selayaknya mahasiswa sebagai kaum terdidik ambil langkah dengan menjadi fasilitator sehingga mampu untuk membaca dan menilai situasi hidup nyata terutama dalam urusan kehidupan antarumat beragama. Ada beberapa langkah atau kebijakan yang bisa diambil untuk merealisasikannya, yaitu pertama, 
adanya dukungan (baik bersikap ataupun berperilaku) untuk menciptakan toleransi antarumat beragama yang dilakukan oleh mahasiswa; kedua, mahasiswa harus mampu untuk mempengaruhi atau mengkampayekan kepada masyarakat untuk selalu menjunjung tinggi sikap toleransi; ketiga, harus ada sikap dan perilaku nyata dari mahasiswa demi terwujudnya persatuan dan kesatuan; keempat, perbedaan dalam keyakinan/agama merupakan modal dasar yang sangat berharga untuk selalu mendengungkan sikap saling toleransi. Inilah modal terbesar apabila mahasiswa menjadi pemimpin bangsa kelak (Bahari, 2010). Sikapsikap yang diperlihatkan berpotensi untuk menciptakan intoleransi antarumat beragama. Mahasiswa sebagai penerus kepemimpinan bangsa ini juga berperan lebih besar sebagai agent of change.

Halsey dan Psacharopoulos (Sosiolog Pendidikan) menyatakan bahwa pendidikan merupakan salah satu bagian penting yang menentukan status sosial dan penghasilan Seseorang akan dipengaruhi oleh pendidikan baik dalam wawasan, cara pandang, dan sikap kritis. Hal inilah yang memungkinkan mahasiswa untuk memikirkan masa depan masyarakat di sekeliling mereka, selaras dengan yang dikatakan oleh William Fulbright bahwa "education is slow but a powerful force". Pengalaman di lapangan menunjukan bahwa munculnya tokoh-tokoh dalam suatu masyarakat salah satunya faktornya adalah karena tingkat pendidikan yang tinggi yang diperoleh selama belajar. Peran mereka sangat dominan dalam perkembangan masyarakat, salah satunya adalah keberagamaan yang harmonis dan hubungan antarumat beragama (Bahari, 2010).

Kajian tentang keberagamaan dan mahasiswa sudah banyak diteliti atau dikaji oleh berbagai kalangan dengan perspektif masing-masing. Hal ini karena keberagamaan merupakan kajian yang sensitif, karena berhubungan dengan keberagamaan masingmasing penganut agama (umat) (K, 2010; Mubarak, 2013; Rahman and Permadi, 2013; Efa Ida Amaliyah, 2014; Wibisono and Taufik, 2017; Ahmad, 2018; Akbar, Amalia and Fitriah, 2018; Alam, 2018). Wibisono dkk, bahwa adanya korelasi positif antara orientasi keberagamaan ekstrinsik dan fundamentalisme agama pada kalangan mahasiswa Muslim dengan nilai $\mathrm{R}=0,329$ dan $\mathrm{p}=0,002(\mathrm{p}<0,01)$ (Wibisono et al., 2017). Institusi pendidikan tinggi memainkan dua peran yaitu pendidikan itu sendiri dan pada saat yang sama mereka menjadi pilar keagamaan bagi masyarakat (Wekke, Hermawanto and Ashrori, 2016). Keberagamaan merupakan suatu sistem penghayatan dan pengamalan agama yang sifatnya relatif diimplementasikan dalam kehidupan sehari-hari dalam bentuk sikap dan perilaku, sebagai wujud interpretasi terhadap ajaran agama yang bersifat absolut. Implementasi ini terjadi dalam interaksi antar individu dalam sebuah masyarakat atau komunitas, dan dalam aspek ritual dan social (Gunansyah, 2005) (Syaefullah, 2007). Penelitian ini memberi warna baru bahwa keberagamaan mahasiswa bidikmisi mempunyai makna yang berbeda sesuai dengan pengalaman dan lingkungan sosial budaya di lingkungan mereka. Mahasiswa bidikmisi merupakan mahasiswa yang mempunyai keistimewaan dalam dua bidang, yaitu bidang akademik dan bidang keberagamaan (rohani).

Religiusitas atau keberagamaan menurut pandangan Islam adalah melaksanakan ajaran agama Islam secara menyeluruh (Muhaimin, et, 2002). Inti keberagamaan ajaran agama Islam adalah Islam sendiri. Hal ini karena ajaran agama Islam ada dalam nilai-nilai kehidupan manusia sehari-hari, yang meliputi ekonomi, hukum, politik, sosial, budaya. Semua bidang tersebut dilaksanakan berlandaskan atau diniatkan untuk beribadah kepada Allah swt. Karenanya, harus tercermin dalam perilaku, tutur kata, dan berfikir umatnya. Seorang muslim dimanapun dan kapanpun hendaknya selalu berislam (Suroso, 1994). Berbagai perilaku agama seseorang atau masyarakat dapat secara umum ditafsirkan sebagai satu kesatuan yang merepresentasikan keberagamaannya (Khadiq, 2009). Sikap eksklusifitas menjadikan agama seakan bersifat antagonis. Antagonisme yang berkembang seputar agama secara garis besar terjadi pada dua tingkatan: 1) ketegangan yang terjadi di kalangan umat beragama itu sendiri, 2) ketegangan yang terjadi antarumat beragama. Sikap keberagamaan orang memiliki perspektif 
yang luas didasarkan pada nilai yang dipilihnya. Selain itu juga dilandasi oleh pendalaman pengertian dan perluasan pemahaman tentang ajaran agama yang dianutnya. Beragama bagi orang dewasa meripakan sikap hidup dan tidak sekedar ikutikutan (Effendy, 2001). Ciri-ciri sikap keberagamaan orang dewasa sesuai dengan tingkat perkembangan, antara lain: 1) Menerima kebenaran agama berdasarkan pertimbangan pemikiran yang matang; 2) Cenderung bersikap realis, sehingga normanorma agama lebih banyak diaplikasikan dalam sikap dan tinh pada tingkah laku; 3) Bersikap positif terhadap ajaran dan normanorma agama dan berusaha untuk mempelajari dan memperdalam pemahaman keagamaan; 4) Tingkat ketaatan beragama didasarkan atas pertimbangan dan tanggungjawab diri, sehingga sikap keberagamaan merupakan realisasi dari sikap hidup; 5) Bersikap terbuka dan berwawasan luas; 6) Bersikap kritis terhadap materi ajaran agama sehingga kemantapan beragama didasarkan atas pertimbangan pikiran dan pertimbangan hati nurani; 7) Sikap keberagamaan cenderung mengarah pada tipe kepribadian masingmasing, sehingga terlihat pada pengaruh kepribadian dalam menerima, memahami, serta melaksanakan ajaran agama yang diyakini; 8) Ada hubungan antara sikap kepribadian dengan kehidupan sosial, sehingga perhatian terhadap kepentingan organisasi sosial keagamaan sudah berkembang.

\section{Sekolah Tinggi Agama Islam Negeri} (STAIN) Kudus mempunyai mahasiswa BIDIKMISI. Bidikmisi merupakan bantuan pendidikan yang diberikan pemerintah bagi mereka yang memiliki potensi tingggi namun tidak memiliki finansial yang mencukupi untuk melanjutkan ke jenjang perguruan tinggi. Mahasiswa bidikmisi yaitu mahasiswa yang mempunyai keistimewaan dari pemerintah dengan memberikan beasiswa kepada mahasiswa yang tidak mampu secara ekonomi tetapi mampu secara prestasi akademik. Mahasiswa tersebut telah disaring melalui beberapa tahap, dan mendapatkan keistimewaan dibanding mahasiswa yang lain. STAIN Kudus mempunyai agenda tersendiri untuk menfasilitasi mahasiswa tersebut yaitu menenmpatkan mahasiswa tersebut di Ma'had
STAIN Kudus dengan memberdayakan kemampuan keberagamaan mereka melalui jalan memakmurkan masjid STAIN Kudus (no date). Ada tiga hal yang menjadi concern STAIN Kudus untuk mencetak mahasiswa yang mempunyai pengetahuan dan mengimplementasikan Islam Transformatif. Tiga hal tersebut adalah, Pertama, pembekalan akademik atau keilmuan terkait dengan pentingnya pengetahuan dan keterampilan. Kedua, pembekalan kepribadian yang diarahkan agar para mahasiswa memiliki kualitas kepribadian yang utuh, menjaga etika dalam aktivitas sehari-hari. Ketiga, pembekalan etik sosial atau bina sikap. Pembekalan ini diarahkan agar mahasiswa penerima Bidikmisi memiliki solidaritas sosial tinggi sehingga mereka mampu menjaga kedamaian dan ketenangan dalam bermasyarakat. Melihat dari sisi keberagamaan tersebut, maka mahasiswa bidikmisi mempunyai kewajiban yang lebih untuk menjalankan keberagamaan tersebut sesuai dengan jadual dan program-program yang sudah dicanangkan oleh pengurus Ma'had tersebut dan STAIN Kudus secara umum.

Keberagamaan mahasiswa bidikmisi berjalan sesuai dengan agenda atau aktifitas yang terjadual. Hal ini memberi peluang mahasiswa selalu mengikuti agenda tersebut, dan menghindari untuk absen atau tidak ikut dalam kegiatan tersebut. Kondisi ini memungkinkan munculnya adanya sikap bosan dari mahasiswa dan yang dikhawatirkan adalah mereka melaksanakan agenda keberagamaan tersebut karena merasa terdesak dan tidak dari kesadaran mereka dalam menjalankan ajaran agama, sehingga ending yang muncul adalah mereka menjalankan keberagamaan bukan sebagai bentuk tanggung jawab umat yang mempunyai agama. Fenomena diatas menggambarkan bahwa mahasiswa bidikmisi mempunyai dua potensi, yaitu potensi akademik bersaing dengan ribuan mahasiswa untuk mendapatkan predikat mahasiswa berprestasi, dan potensi rohaniah, mahasiswa bidikmisi mendapatkan kesempatan untuk "memakmurkan" masjid STAIN Kudus melalui kegiatan keagamaan.

Tulisan ini mengungkap tentang dua hal, pertama, apa makna keberagamaan mahasiswa 
bidikmisi TA.2014? kedua, bagaimana bentuk keberagamaan mahasiswa bidikmisi TA.2014?.

\section{METODOLOGI}

Jenis penelitian ini adalah field research, yaitu penelitian yang dilakukan di lapangan atau medan terjadinya gejala-gejala (Hadi, 1995). Pendekatan yang akan digunakan adalah menentukan SA (satuan analisis), SP (satuan pengamatan), SI (sumber informasi). Satuan Analisis merupakan mahasiswa bidikmisi STAIN Kudus. Sedangkan Satuan Pengamatan adalah Satuan Analisis. Sumber Informasi adalah bentuk dan makna keberagamaan mahasiswa bidikmisi STAIN Kudus.

Penelitian ini tidak hanya pada pemaparan pemaknaan mengenai keberagamaan dari mahasiswa STAIN Kudus saja, melainkan berusaha mendapatkan nilainilai yang terkandung didalamnya. Dengan demikian, diharapkan ada tindak nyata dari mahasiswa setelah mereka menemukan realitas social yang ada disekeliling mereka dengan memberikan bekal pengetahuan agama sehingga agama dan keberagamaan bukan menjadi sebuah ritualitas dan konsep semata.

Penelitian ini dilakukan di STAIN kudus, khususnya mahasiswa bidikmisi Tahun Anggaran 2015 yang mempunyai kewajiban untuk mengikuti agenda atau kegiatan keagamaan di masjid STAIN Kudus. Kegiatan ini menjadi indikator keberagamaan mereka, karena mahasiswa dituntut untuk menjalankan program yang sudah ada. Melihat pola keberagamaan mahasiswa tersebut, maka secara sekilas terlihat bentuk keberagamaan mereka. Meskipun demikian, untuk mengungkap makna keberagamaan di kalangan mahasiswa harus dilihat

Penulis menggunakan teknik observasi partisipasi pasif (passive participation). Observasi dilakukan untuk melihat fenomena atau gejala di lapangan yang berhubungan dengan bantuan tersebut. Wawancara dilakukan untuk memperoleh informasi lebih dalam mengenai fakta yang relevan dengan bantuan, karena apa yang terlihat belum mengungkap apa sebenarnya yang terjadi. Peneliti mewawancarai beberapa orang dengan menggunakan teknik snowballing yang mempunyai latar belakang berbeda, baik tingkat pendidikan, usia, dan strata social.
Selain melalui sumber manusia, dalam mendapatkan data yang lebih akurat, peneliti juga mengumpulkan data melalui sumber dokumen. Dokumentasi adalah metode pengumpulan data dengan menggunakan dokumen yang ada. Dokumentasi adalah alat perekam peristiwa foto-foto saat pelaksanaan, selain itu juga dokumen-dokumen yang di dapat dari kegiatan yang dilakukan oleh Ma'had yang difokuskan di Masjid STAIN Kudus. Dokumentasi ini sangat menunjang sebagai bukti konkret yang ada di lapangan baik dari kondisi kegiatan dan implementasi keberagamaan tersebut.

Data yang sudah dikumpulkan, disaring dan kemudian dianalisa sesuai dengan kategorisasi yang dilakukan, sehingga mendapatkan data yang valid dengan menghubungkan data-data yang ada. Tahap selanjutnya adalah dengan menyimpulkan dari semua deskripsi yang sudah disajikan. Dalam menganalisa data, peneliti menggunakan metode deskripsi kualitatif dengan menggunakan tahap reduksi, eksplorasi, menverifikasi dan mengkontekstualisasikan data sehingga diharapkan mendapat makna keberagamaan mahasiswa bidikmisi TA 2015.

\section{HASIL DAN PEMBAHASAN}

\section{Selayang Pandang Tentang Bidikmisi STAIN Kudus}

Bidikmisi atau Beasiswa Pendidikan Mahasiswa adalah salah satu program DIKTI Kementerian Pendidikan Nasional tahun 2010, yaitu untuk memberikan bantuan biaya penyelenggaraan pendidikan dan bantuan biaya hidup kepada mahasiswa yang memiliki potensi akademik memadai dan kurang mampu secara ekonomi (No Title, no date).

Ada beberapa tujuan bidikmisi yang diharapkan tercapai untuk mengakomodasi kebutuhan mahasiswa yang kurang mampu secara finansial, antara lain (No Title, no date): 1) Meningkatkan motivasi belajar dan prestasi calon mahasiswa, khususnya mereka yang menghadapi kendala ekonomi; 2) Meningkatkan akses dan kesempatan belajar di perguruan tinggi bagi peserta didik yang berpotensi akademik memadai dan kurang mampu secara ekonomi; 3) Menjamin keberlangsungan studi mahasiswa sampai selesai dan tepat waktu; 4) Meningkatkan prestasi mahasiswa, baik pada bidang akademik/kurikuler, ko-kurikuler maupun ekstra 
kurikuler; 5) Menimbulkan dampak iring bagi mahasiswa dan calon mahasiswa lain untuk selalu meningkatkan prestasi; 6) Melahirkan lulusan yang mandiri, produktif dan memiliki kepedulian sosial, sehingga mampu berperan dalam upaya pemutusan mata rantai kemiskinan dan pemberdayaan masyarakat.

Mahasiswa bidikmisi STAIN Kudus mempunyai visi untuk mencetak intelektual ulama dan ulama intelektual, sedangkan untuk misinya sesuai dengan output yang diinginkan dari mahasisiwa bidikmisi, yaitu antara lain: 1) Mahasiswa Program Bidikmisi Memahami Hakikat Kuliah di STAIN Kudus; 2) Mahasiswa Program Bidikmisi Mahir Berbahasa Arab; 3) Mahasiswa Program Bidikmisi Mahir Berbahasa Inggris; 4) Mahasiswa Program Bidikmisi Minimal Hafal 5 Juz dari al-Qur'an; 5) Mahasiswa Program Bidikmisi Mampu Memahami Kitab Kuning; 6) Mahasiswa Program Bidikmisi Mampu Memahami Buku Berbahasa Inggris; 7) Mahasiswa Program Bidikmisi Mampu Menyusun Karya Ilmiah; 8) Mahasiswa Program Bidikmisi Memiliki Keahlian Entrepreneurship.

\section{Kondisi Sosial-Ekonomi Mahasiswa Bidikmisi Tahun Anggaran 2014}

Mahasiswa bidikmisi adalah mahasiswa yang mendapatkan keistimewaan (privilage). Mahasiswa bidikmisi merupakan mahasiswa pilihan, karena dua hal: pertama, potensi akademik bersaing dengan ribuan mahasiswa untuk mendapatkan predikat mahasiswa berprestasi, kedua, potensi rohaniah, mahasiswa bidikmisi mendapatkan kesempatan untuk "memakmurkan" masjid STAIN Kudus melalui kegiatan keagamaan.

Kondisi ekonomi sosial mahasiswa merupakan dari keluarga yang sederhana, dengan mata pencaharian dari kedua orangtua yang tidak tentu dengan pendapatan $<1$ Juta. Kondisi ekonomi sosial mahasiswa diketahui ketika STAIN Kudus mengirimkan tim untuk melakukan pengecekan dan mengevaluasi penemuan kondisi real di lapangan, yaitu kondisi fisik tempat tinggal calon mahasiswa dan juga hasil wawancara tentang situasi atau kondisi orangtua calon mahasiswa. hasil temuan tersebut kemudian dilakukan penyaringan di tingkatan STAIN Kudus.
Berdasarkan temuan di lapangan, mayoritas pendapatan atau perekonomian orangtua mahasiswa bidikmisi adalah mahasiswa yang kurang mampu. Meskipun demikian, potensi mahasiswa tersebut bagus (excellent) dalam bidang akademik. Inilah yang membedakan mahasiswa bidikmisi dengan mahasiswa bukan penerima beasiswa bidikmisi yang berjumlah 30 mahasiswa.

Sebagaimana yang dikemukakan oleh Dina Juz Hayya (Mahasiswa Jurusan Ushuluddin Prodi Ilmu Aqidah berasal dari Jepara):

"saya adalah putri dari pasangan bapak
sabakun (Alm) dan ibu sulistyowati dari
desa lebak RT O2 RW O1 Pakis aji
jepara, saya adalah anak pertama dari
tiga bersaudara, ayah saya meninggal
dunia sejak saya berumur 13 tahun. Dan
sekarang saya tinggal bersama ibu dan
kedua adik saya. Ibu saya bekerja
sebagai TU (tata usaha) di madrasah
tsanawiyah di desa saya yang
berpenghasilan di bawah 1.000.000 dan
juga merangkap sebagai ibu rumah
tangga, dan menyekolahkan saya dan
adik-adik saya, yang saya sendiri sedang
di bangku kuliah sedang adik laki-laki
saya di bangku SMK dan adik
perempuan saya yang berada di bangku
sekolah dasar. Ibu saya sendirian
mengurusi rumah dan sekaligus bekerja
mencari nafkah" (Wawancara tanggal 1
Juli 2015).

Hal lain juga disampaikan oleh Saifuddin Zuhri (Mahasiswa Jurusan Tarbiyah Prodi Pendidikan Agama Islam berasal dari Pati):

"Saya anak dari pasangan Bapak Sugiyanto dan Ibu Suprihati, saya anak pertama dari 2 saudara saya mempunyai adik yang masih sekolah di MIN kelas 3. Pekerjaan kedua orang tua saya adalah pedagang, pekerjaan ibu saya sebagai penjual kecambah di pasar dan pekerjaan bapak saya adalah sebagai penjual buku, kitab, dan aksesoris yang berjualan dipinggir jalan. Pendapatan kedua orang tua saya selama satu bulan kurang dari Rp. 1.000.000 yang untuk menghidupi saya, adik saya, dan kedua 
orang tua saya." (Wawancara tanggal 1 Juli 2015)

\section{Kegiatan Mahasiswa Bidikmisi}

Mahasiswa bidikmisi memiliki kegiatan yang sangat beragam, baik dari segi intelektual maupun keagamaan. Kegiatan tersebut menambah pengetahuan (knowledge) untuk mereka, sehingga membantu meningkatkan prestasi baik dari sisi agama atau indek prestasi (IPK). Adapun kegiatan tersebut dalam tiga kegiatan, seperti tabel 1, 2, 3 dan 4.

Tabel 1. Kegiatan Harian

\begin{tabular}{|c|c|c|c|c|}
\hline No. & Nama Kegiatan & Hari & Waktu & Tempat \\
\hline \multirow[t]{2}{*}{1} & Tadarus Al-Qur'an & Setiap hari & Setelah Maghrib & Masjid \\
\hline & Speech Program & & $19.30-20.30$ & Depan Masjid \\
\hline \multirow[t]{3}{*}{2} & Debate Program & Senin & $21.00-22.00$ & Ma'had \\
\hline & Vocabulary & & $05.00-06.00$ & Ma'had \\
\hline & Speech Program & & $19.30-20.30$ & Masjid \\
\hline \multirow[t]{2}{*}{3} & Debate Program & Selasa & $21.00-22.00$ & Ma'had \\
\hline & Reading & & $05.00-06.00$ & Ma'had \\
\hline \multirow{2}{*}{4} & Diskusi Pengetahuan Umum & Rabu & $21.00-22.00$ & Ma'had \\
\hline & Listening & Kabu & $05.00-06.00$ & Ma'had \\
\hline \multirow{2}{*}{5} & Berjanjenan & & $19.30-21.00$ & Masjid \\
\hline & Seniority Class /Telling Story & Kamis & $05.00-06.00$ & Ma’had \\
\hline 6 & Review & Jum'at & $05.00-06.00$ & - \\
\hline 7 & Kumpul-Kumpul & Senin \& Selasa & 16.00 - Selesai & Belakang Rektorat \\
\hline
\end{tabular}

Tabel 2. Kegiatan Mingguan

\begin{tabular}{ccccc}
\hline No. & Nama Kegiatan & Hari & Waktu & Tempat \\
\hline 1 & Maulid Diba'an & Ahad & $19.30-$ Selesai & Masjid \\
2 & Yasinan \& Tahlilan & Kamis & Setelah Maghrib & Masjid \\
3 & Berjanjenan & Kamis & Setelah Isya' & Masjid \\
4 & Evaluasi Program & Ahad & $20.30-22.00$ & Ma'had \\
5 & Rebana/Qiro'ah/Bilal Jum'at & Kamis & $21.00-22.00$ & Masjid \\
6 & Setoran Juz Amma' & Setiap Hari & - & Masjid \\
\hline
\end{tabular}

Tabel 3. Kegiatan Bulanan

\begin{tabular}{cccc}
\hline No. & Nama Kegiatan & Hari & Tempat \\
\hline 1 & Khataman Al-Qur'an & Awal Bulan & Masjid \\
2 & Pembinaan Mahasiswa Bidikmisi & Setiap Bulan & Rektorat \\
3 & Penelitian Mahasiswa & September & - \\
4 & Presentasi Hasil Penelitian & Oktober & Rektorat \\
\hline
\end{tabular}

Tabel 4. Kegiatan Tahunan

\begin{tabular}{cccc}
\hline No. & Nama Kegiatan & Waktu & Tempat \\
\hline 1 & Happy Ramadlan & Bulan Puasa & Masjid \\
2 & Santunan Anak Yatim & Bulan Syuro & Masjid \\
3 & Sekolah Bahasa Asing & Libur Semester & Pare Kediri \\
4 & Peringatan Maulid Nabi & Bulan Mulud & Masjid \\
5 & Penyambutan Mahasiswa Bidikmisi (Baru) & Oktober & Ma'had \\
6 & Pelatihan Jurnalistik \& Makalah & Oktober & Ma'had \\
\hline
\end{tabular}


Adanya kegiatan yang banyak sangat membantu mahasiswa untuk meningkatkan kualitas waktu dan pergaulan, karena mereka bertemu untuk menyelesaikan kegiatan yang sangat positif. Sebagaimana yang diungkapkan oleh Zaenal Muttaqien (Mahasiswa Tarbiyah prodi Pendidikan Agama Islam berasal dari Wirosari):

"alkhamdulillah, Setelah tinggal dan mengikuti seluruh agenda yang ada di ma'had STAIN Kudus, mulai perlahan sikap dan kepribadian saya mulai berubah kearah yang lebih baik. Yang awalnya ngaji hanya setelah magrib, sekarang setiap selesai sholat, terutama sholat jama'ah, saya mulai rutin mengaji. sikap menghargai orang lain pun mulai tumbuh karena di Ma'had STAIN Kudus saya tidak hidup sendiri, saya harus bisa hidup berbagi dengan santri - santri ma'had yang lain. Selain itu saya sedikit jarang sudah mulai mengistiqomahkan sholat malam, sholat dhuha dan puasa sunnah. Dari segi intelektual pun banyak yang saya dapatkan, mulai dari pengetahuan agama sampai pengetahuan umum. Pengetahuan agama saya dapatkan dalam kajian kitab - kitab atau masalah mengenai keagamaan. Sedangkan, pengetahuan umum serta kemampuan menyelesaiakan masalah up to date saya dapatkan dari kegiatan diskusi mingguan yang ada di Ma'had STAIN Kudus, dan masih banyak lagi". (Wawancara dilakukan tanggal 29 Juni 2015).

Hal yang sama disampaikan oleh Misbahul (Mahasiswa Syariah dan EI / Ekonomi Syariah, asal Jepara:

"Rangkaian kegiatan yang saya ikuti di ma'had diantaranya ada kegiatan harian, bulanan, tahunan dan sebagainya. Kegiatan Harian meliputi sholat berjama'ah, tadarus al - Qur'an Q.S Al Mulk, setelah isya' Q.S Al Hasyr, Ba'da Shubuh Q.S Ar - Rahman dan Waqiah. English dan Arabic Area, kegiatan mingguan seperti Berjanjenan, Diskusi Umum, Maulid Diba', latihan Rebana dsb. Kegiatan Peringatan Hari Besar Islam seperti Peringatan Nuzulul
Quran, Ramadhan In Ma'had dan beberapa kegiatan didalamnya seperti Tahtimul Quran, Pengajian Kitab, Aksi Sosial, Diskusi Keagamaan dan sebagainya. Kegiatan bulanan Penerbitan Majalah, Ziarah, doa bersama menjelang Test UTS ataupun UAS, dan masih banyak kegiatan yang saya jalankan di Ma'had ini.

Kegiatan kegamaan di Ma'had itu sendiri baik. Selain itu juga memberikan kontribusi yang begitu bermanfaat bagi pribadi saya sendiri. Di antaranya dapat menambah wawasan dan pengetahuan tentang keagamaan. Menambah khazanah keislaman. Dan saya juga sadar bahwa rangkaian tersebut banyak sisi positif yang saya peroleh, saya mulai disiplin dalam melaksanakan kegiatan, menambah wawasan dan keilmuan khususnya di bidang keagamaan". (Wawancara dilakukan tanggal 29 Juni 2015).

Lain halnya apa yang dirasakan Dina Juz Hayya (Mahasiswa Jurusan Ushuluddin Prodi Ilmu Aqidah berasal dari Jepara, merasakan perbedaan setelah mengikuti kegiatan yang diadakan oleh ma'had:

"Setelah saya berada di makhad kegiatan keagamaannya lumayan banyak diantaranya adalah dimulai pada malam senin dia adakan acara maulid ndiba', lalu setiap hari setelah sholat jamaah magrib biasanya membaca al-quran bersama-sama. Dan setiap hari setelah solat subuh membaca surat waqiah dan ar-rahman. Acara yang lainnya yaitu adanya do,a bersama menjelang UAS dan UTS, adanya wisata religi bersama ke makam sunan kudus, muria dan sunan kalijaga. Kegiatan posonan yang rutin dilakukan ketika bulan ramadhan selama kurang lebih 3 minggu. Selain adanya kegiatan keagamaan ada juga kegiatan pengembangan diri seperti pengembangan bahasa inggris dan bahsa arab yang pernah kita dapat di pare, yang di adakan pada pagi hari setelah subuh dan malam hari setelah isya'. kegiatan-kegiatan keagamaan seperti itu sangatlah bagus, selain 
mendapat pahala kita juga bisa mendapatkan siramn rohani, hati menjadi tenang, dan dengan kegiatan seperti itu lebih mendekatkan diri kita pada tuhan dan menimbulkan adanya kebersamaan dan persaudaraan antara kita keluarga besar makhad. Lalu seperti acara posonan, kita jadi mendapatkan ilmu dari ngaji kitab selain juga mendapat pahala yang berlipat ganda dan rasanya waktu berbuka tak kerasa. Dari pada kita hanya berdiam diri dan tidur-tidur saja. Lalu dengan adanya kegiatan pengembangan bahasa kita juga bisa tetap mengingat pelajaran yang pernah kita dapat di pare agar tetap ingat dan tidak lupa. Dan kita juga bisa mengaplikasikannya. Ya kira-kira seperti itu dan masih banyak dampak positif lainnya." (Wawancara dilakukan tanggal 29 Juni 2015).

Kegiatan tersebut terjadwal secara rapi dan dilaksanakan secara kolektif juga. Kegiatan tersebut dilaksanakan dengan tidak berbenturan jadwal perkuliahan mahasiswa, sehingga waktunya pada malam hari. Tempatnya di ma'had atau di masjid. Kegiatan tersebut merupakan ajang silaturahim untuk mengakrabkan antar mahasiswa. Hal tersebut karena mereka dari jurusan dan prodi yang berbeda. Selain itu, kegiatan yang ada menjalin kerjasama untuk saling berbagi tentang berbagai hal seperti masalah personal, keluarga juga termasuk tentang materi perkuliahan. Adanya kegiatan tersebut dapat mengontrol tentang keberadaan mereka terutama dalam bidang akademik.

\section{Makna keberagamaan Mahasiswa Bidikmisi Tahun Anggaran 2014}

Mahasiswa bidimisi STAIN Kudus memberi makna keberagamaan sangat beragam. Hal tersebut sesuai dengan pengetahuan mereka tentang konsep tersebut dengan melihat fenomena atau realita dan juga pengalaman individu di sekitar mereka. Sebagaimana yang dijelaskan oleh Jamaluddin Ancok dan Suroso bahwa keberagamaan seseorang memiliki beberapa dimensi, yaitu Keyakinan Agama (Ideologis), Peribadatan atau praktik Agama (Ritualistik), Pengetahuan Agama (Education), Penghayatan
(Eksperiensial), Pengamalan Agama (Konsekuensial). Karenanya, masing-masing individu berbeda dalam keberagamaan (Suroso, 1994).

Sebagaimana yang dikemukakan oleh Khabibur Rohman (Mahasiswa Tarbiyah prodi Pendidikan Agama Islam berasal Kudus:

"Saya lulusan MA Qudsiyyah Kudus, sekolah yang berbasis keagamaan yang disuguhi dengan kitab - katab kuning, setiap hari pelajaran kitab kuning sangat kental dengan mempelajari ilmu fiqih, ilmu nahwu, ilmu falak, ilmu tafsir dan sebagainya, di samping itu saya juga bertempat tinggal di pondok pesantren Ma'had Al Maimuniyyah dengan mengkaji dan mempelajari kitab fiqih, setiap malam berdiskusi atau musyawarah tentang ilmu fiqih, dan subuhnya sorogan atau membaca kitab kuning di hadapan kiyai. Dengan adanya kegiatan di ma'had ini saya merasa terbantu dengan peningkatan skill pada diri saya sendiri, kegiatan di ma'had sangat membantu saya menyesuaikan kehidupan dalam kampus dan kehidupan dalam masyarakat, saya merasa berbeda dengan teman-teman saya di kelas semenjak saya tinggal di ma'had, seperti berdiskusi aktif di kelas dan memberikan argumen yang rasional, memberi pengetahuan yang saya ketahui kepada teman yang bertanya bahasa inggris. Di luar kampus saya tersentuh dengan kegiatan sosialisasi kepada anak jalanan yang ingin bersekolah, akan tetapi kurangnya biaya dalam kehidupannya menjadikan anak-anak tersebut kurang mampu. Dan semua apa yang saya dapat saya akan mengamalkan kepada orangorang." (Wawancara dilakukan tanggal 29 Juni 2015)

Berbeda dengan yang dirasakan oleh Zaenal Muttaqin (Mahasiswa Tarbiyah prodi Pendidikan Agama Islam berasal dari Wirosari:

"Saya adalah seorang mahasiswa alumni dari SMK N 1 Wirosari, sebuah sekolah negri formal yang tidak terdapat mata pelajaran agama kecuali pai. Dirumah pun saya hanya memperoleh 
pendididkan agama dari madin yang masih sangat minim tenaga pengajar. Oleh karena itu saya merasa bahwa pengetahuan agama yang saya miliki masih sangat minim sekali. Akan tetapi saya tidak puas dengan pengetahuan agama yang saya miliki waktu itu, sehingga saya ingin terus menambah pengetahuan agama saya, salah satunya yaitu dengan melanjutkan pendidikan saya di STAIN Kudus, yaitu PT yang berbasis agama, berharap supaya menjadi lebih baik akhlaq dan pengetahuan saya terutama pengetahuan agama." (Wawancara dilakukan tanggal 29 Juni 2015)

Hal lain juga disampaikan oleh Devi Anggraini (Mahasiswa Syariah prodi Ekonomi Syariah asal Jepara):

"Sebelum saya di ma'had, saya tidak seperti ini. Yang belum mengerti agama begitu dalam dan rajin mengaji. Dulu asal sekolah saya di SDN 02 Nalumsari, SMPN 02 Nalumsari yang tidak ada banyak pengajaran tentang agama disana. Setelah itu saya meneruskan di MA ANNUR Daren, sekolah yang letaknya di pelosok dan bisa dibilang kurang maju. Karena tempatnya yang tidak banyak diketahui orang-orang dan gurunya yang jarang mengajar dan jarang masuk. Sehingga disaat ujian pada angkatan saya pun tidak diadakan hafalan-hafalan serta ujian praktik tentang keberagamaan, dan praktik agama yang lain. Selain itu saya tidak pernah keluar jika dirumah, sehingga mengikuti organisasi-organisasipun saya tidak pernah seperti IPNU, Jami'iyah, dan lain-lain. Sehingga beda jauh di waktu saya sudah berada di ma'had. Makna positif bagi saya sangat banyak, diantaranya bisa mendekatkan diri kepada allah dengan berbagai macam cara seperti mengaji, mengerti arti kebersamaan, peduli satu sama lain, kepemimpinan yang baik, sopan santun, etika yang baik, dan juga di mahad tidak hanya di ajarkan tentang keberagamaan tetapi juga tentang dunia modern. Seperti halnya pengajaran bahasa setiap hari, bahasa inggris dan bahasa arab, juga tentang pengajaran-pengajaran yang lain yaitu seperti tentang jurnalistik dan lain-lain. Juga di ajarkan tentang nilai kehidupan, saling tolong menolong, sehingga sering di lakukan aksi turun kejalan langsung oleh semua anggota ma'had. Dampak positif saya setelah berada di ma'had juga masih banyak lagi. Bisa lancar mengaji dibandingkan sebelum saya belum berada di ma'had yang dulunya membaca al Qur'an sehari hanya satu kali sekarang bisa berkalikali, bisa lebih menata kepribadian diri yang baik, dan semua hal yang bersangkutan dengan agama bisa lebih baik dan juga masih banyak lagi". (Wawancara dilakukan tanggal 29 Juni 2015)

Makna keberagamaan bagi mahasiswa bidikmisi tidak berhubungan dengan sikap keberagamaan, tetapi memaknai dari praktik ibadah yang mereka lakukan, baik ibadah sunnah dan ibadah wajib. Keberagamaan mahasiswa mengalami peningkatan dalam segi kuantitas. Secara kuantitas dengan beragamnya kegiatan di ma'had menambah nilai keberagamaan mereka, sedangkan secara kualitas mereka merasakan dalam perilaku sehari-hari. Mereka merasakan perubahan dalam perilaku yang lebih alim dan sopan serta memiliki etika baik terhadap sesama.

Keberagamaan sesorang selalu berubah sesuai dengan kondisi atau situasi lingkungan. Hal ini berhubungan dengan keimanan (kadar iman), karena sifat iman fluktuatif, kadang bertambah kadang berkurang. Menurut Imam Ibnul Qayyim rahimahullah menuturkan, "Hasil usaha jiwa dan qolbu (hati) yang terbaik dan penyebab seorang hamba mendapatkan ketinggian di dunia dan akherat adalah ilmu dan iman. Oleh karena itu Allah Ta'ala menggabung keduanya dalam firmanNya,

وقال الذين أونوا العلم والإيمان لقد لبثتم في كتاب اله إلى يوم البعث

"Dan berkata orang-orang yang diberi ilmu pengetahuan dan keimanan (kepada orang-orang yang kafir): "Sesungguhnya kamu telah berdiam (dalam kubur) menurut ketetapan Allah, 
sampai hari berbangkit." (QS ar-Ruum: 56)

Dan firman Allah Ta'ala,

$$
\text { يرفع الله الذين آمنوا منكم و الذين أوتوا العلم درجات }
$$

"Niscaya Allah akan meninggikan orang-orang yang beriman di antaramu dan orang-orang yang diberi ilmu pengetahuan beberapa derajat." (QS alMujaadilah: 11).

\section{PENUTUP}

Mahasiswa bidikmisi merupakan mahasiswa yang mempunyai keistimewaan dalam dua bidang, yaitu bidang akademik dan bidang keagamaan. Potensi akademik bersaing dengan ribuan mahasiswa untuk mendapatkan predikat mahasiswa berprestasi. Mahasiswa tersebut merupakan mahasiswa yang secara ekonomi dari kalangan menengah ke bawah, sehingga mereka berjuang untuk mendapatkan predikat sebagai mahasiswa. Hal ini didukung oleh kemampuan akademik yang bagus dan memuaskan melalui tes yang diselenggarakan oleh Kemenag Pusat melalui STAIN Kudus. Potensi rohaniah, mahasiswa bidikmisi mendapatkan kesempatan untuk "memakmurkan" masjid STAIN Kudus melalui kegiatan keagamaan. Memakmurkan masjid inilah yang mempengaruhi keberagamaan mahasiswa bidikmisi. Kegiatan ini yang mempengaruhi peningkatan keberagamaan mereka karena bernuansa agamis. Kegiatan tersebut antara lain barzanji, ngaji kitab, maulid diba'an, yasinan dan tahlil, qira'ah, dan hafalan juz 'amma.

Kegiatan tersebut terjadwal secara rapi dan dilaksanakan secara kolektif juga. Kegiatan tersebut dilaksanakan dengan tidak berbenturan jadwal perkuliahan mahasiswa, sehingga waktunya pada malam hari. Tempatnya di ma'had atau di masjid. Kegiatan tersebut memberi makna keberagamaan bagi mahasiswa. Makna keberagamaan bagi mahasiswa bidikmisi tidak berhubungan dengan sikap keberagamaan, tetapi memaknai dari praktik ibadah yang mereka lakukan, baik ibadah sunnah dan ibadah wajib. Keberagamaan mahasiswa mengalami peningkatan dalam segi kuantitas. Secara kuantitas dengan beragamnya kegiatan di ma'had menambah nilai keberagamaan mereka, sedangkan secara kualitas mereka merasakan dalam perilaku sehari-hari. Mereka merasakan perubahan dalam perilaku yang lebih alim dan sopan serta memiliki etika baik terhadap sesama.

\section{UCAPAN TERIMAKASIH}

Terimakasih kami ucapkan kepada semua pihak yang berperan dalam proses penelitian ini. Khususnya kepada Kepala TK/RA dan seluruh guru di RA Assalaam Manado, RA Ar Rahmah Manadodan TK YAPIM Manado yang telah memberikan izin untuk melaksanakan kegiatan penelitian ini serta membantu memberikan infomasi yang dibutuhkan. Ucapan terima kasih juga disampaikan kepada tim editor Jurnal Edukasi yang telah memberikan saran, kritik, dan rekomendasi untuk perbaikan artikel ini.

\section{DAFTAR PUSTAKA}

Ahmad, A. K. (2018) 'Orientasi Pemikiran Keagamaan Mahasiswa', Al-Qalam. doi: 10.31969/alq.v3i2.657.

Akbar, M. Y. A., Amalia, R. M. and Fitriah, I. (2018) 'Hubungan Relijiusitas dengan Self Awareness Mahasiswa Program Studi Bimbingan Penyuluhan Islam (Konseling) UAI', Jurnal Al-Azhar Indonesia Seri Humaniora. doi: 10.36722/sh.v4i4.304.

Alam, L. (2018) 'Islamization, Piety, Fundamentalism: Religious Movement In Campus', Islam Realitas: Journal of Islamic \& Social Studies. doi: 10.30983/islam_realitas.v4i2.785.

Bahari (2010) Toleransi Beragama Mahasiswa (Studi tentang Pengaruh Kepribadian, Keterlibatan Organisasi, Hasil Belajar Pendidikan Agama, dan Lingkungan Pendidikan terhadap Toleransi Mahasiswa Berbeda Agama pada 7 Perguruan Tinggi Umum Negeri). Jakarta: Badan Litbang dan Diklat Puslitbang Kehidupan Keagamaan Kementerian Agama RI.

Efa Ida Amaliyah (2014) 'Konsep Dan Komitmen Mahasiswa Stain Kudus Tentang Pluralitas Agama', Fikrah. 
Effendy, B. (2001) Masyarakat Agama dan Pluralisme Keagamaan. Yogyakarta: Galang Press.

Gunansyah, A. (2005) 'Spiritual Intelligence (SQ) and Peace Education Exploration on Peace toward a Sustainable Development in Post-Conflict Area of North Maluku'.

Hadi, S. (1995) Metodologi Research. Yogyakarta: Andi Offset.

Hajar, I. (2005) kemerosotan religiusitas. Available at: www. Suaramerdeka.com (Accessed: 16 July 2015).

Ilyas, H. (2014) 'Keberagamaan Otentik dalam Al-Qur'an', Analisa, 21(01).

K, N. (2010) Pengaruh Tingkat Keberagamaan Terhadap Prestasi Belajar Mahasiswa Angkatan 2007/2008 Jurusan Pai Fakultas Tarbiyah Dan Keguruan Uin Alauddin Makassar, Uin Alauddin Makasar. doi: 10.1007/s00122013-2240-4.

Khadiq (2009) Islam dan Budaya Lokal (Belajar Memahami Realitas Agama dalam Masyarakat),. Yogyakarta: Teras.

Mubarak, M. Z. (2013) 'Dari Semangat Islam Menuju Sikap Radikal: Pemikiran dan Perilaku Keberagamaan Mahasiswa UIN Syarif Hidayatullah Jakarta', Ma'arif.

Muhaimin, et, A. (2002) paradigma Pendidikan Islam: Upaya Mengefektifkan PAI di Sekolah. Bandung: Remaja Rosda Karya.

Peter Carnolly, E. (1999) Aneka Pendekatan Studi Agama. Yogyakarta: LKIS.
Rahman, A. A. and Permadi, R. (2013) 'Pengaruh Identitas Keberagamaan Dan Kejijikan Moral Terhadap Perilaku Cybersex', Psikologika: Jurnal Pemikiran dan Penelitian Psikologi. doi: 10.20885/psikologika.vol18.iss1.art2.

Subakri (2004) 'Pola pendidikan agama islam di pondok pesantren al-muayyad mangkuyudan - solo', Crcs Ugm.

Suroso, D. A. dan (1994) Psikologi Islam: Solusi Islam atas problem-problem psikologi. Yogyakarta: Pustaka Pelajar.

Syaefullah, A. (2007) Merukunkan Umat Beragama. Jakarta: Grafindo Khazanah Ilmu.

Wekke, I. S., Hermawanto, A. and Ashrori, M. (2016) 'Wilayah Minoritas Muslim', 17(2), pp. 135-146.

Wibisono, S. et al. (2017) 'Orientasi Keberagamaan Ekstrinsik Dan Fundamentalisme Agama Pada Mahasiswa Muslim: Analisis Dengan Model Rasch', 15(01), pp. 1-11. doi: 10.7454/jps.2017.1.

Wibisono, S. and Taufik, M. (2017) 'Orientasi Keberagamaan Ekstrinsik dan Fundamentalisme Agama pada Mahasiswa Muslim: Analisis dengan Model Rasch', Jurnal Psikologi Sosial. doi: 10.7454/jps.2017.1.

(No date) 'No Title'. Available at: http://suaramerdeka.com/v1/index.php/re $\mathrm{ad} /$ cetak/2013/10/21/240678/STAINKudus-Bekali-Penerima-Bidikmisi. 